\title{
Depression among B.Ed college students
}

\author{
Ramesh O. Prajapati*
}

\begin{abstract}
Aim of the research is to find out the depression among B.ed College students, So, investigator selected two groups one is male and other is female, both groups have 120 students. In each group has 60 male and other one groups has 60 female students. Data were collected from different collages of v.v.nagar city. Scale was use for data collection is personal datasheet and depression scale developed by A.T. Back (1967), 2x2 factorial design was used and data were analysis by ANOVA test. Result show, There is significant difference between the depression among male and female B.ed college student. There is significant difference between the depression among urban and rural B.ed college student. There is significant difference between the effect of interaction on depression among type of sex and type of area of B.ed college student.
\end{abstract}

\section{INTRODUCTION}

Everyone has experienced feelings of depression at one time or another. Each person's experience of depression is different as there is a wide variety of symptoms. Many people feel down occasionally, or go through bad patches, but have areas in their lives that make them feel good, and like things about themselves. For some people though, life is more of a struggle. They feel bad about themselves and their lives in most ways. At times they feel complete despair. If you feel like this, then you may be depressed.

\section{What is depression?}

Depression is prolonged and persistent mood which can color and interfere with many aspects of one's life. It is characterized by feelings of worthlessness, excessive guilt, loneliness, sadness, hopelessness, self-doubt and guilt. Suicidal thoughts may also be present. Normal everyday depression can last for a few minutes to a few days. We've all felt these-

\footnotetext{
*Ph.D Student, Department of Psychology, S.P.University, V.V.Nagar, Gujarat.
} 
periods of being "down" or "sad". These feelings are a normal part of being human. On the other hand, depression that becomes intense and lasts for extended periods of time is beyond the everyday sort. For this more severe depression you need to consider getting help.

\section{What may cause people to be depressed?}

Significant loss

$>$ Feeling a lost of control over life events

$>$ Unrealistic expectations

$>$ Disappointment

Negative thinking

\section{Symptoms of depression}

Emotional symptoms

Sadness

$>$ Anxiety

$>$ Guilt

$>$ Anger

$>$ Mood swings

$>$ Helplessness

$>$ Hopelessness

Physical symptoms

$>$ Sleeping too much or too little

$>$ Over-eating or loss of appetite

$>$ Constipation

$>$ Weight loss or gain

Irregular menstrual cycle

$>$ Gradual loss of sexual desire

Behavioral symptoms

$>$ Crying for no apparent reason

$>$ Withdrawal from other people and new situations

$>$ Getting angry easily

$>$ Being unmotivated to set or meet goals

$>$ Loss of interest in one's physical appearance 
The International Journal of Indian Psychology: Volume: 01 | Issue: 03 | ISSN 2348-5396

$>$ Loss of interest in activities which were once of

$>$ interest

Turning to drugs or alcohol

\section{How to help a depressed person}

$>$ Do not tell the person that you know what

$>$ She/he is feeling. This may make them angry.

$>$ Be supportive and patient

$>$ Let the person know that you are concerned and that you will be there for them.

$>$ Encourage the person to seek professional

$>$ Help if symptoms persistent and seem to

$>$ Interfere with activities for daily living.

\section{AIMS OF THE STUDY:}

1. To study of the Depression among male and female B.ed college student.

2. To study the Depression among urban and rural B.ed college student.

3. To study of the effect of interaction on Depression among type of sex and type of area B.ed college student.

\section{HYPOTHESIS:-}

1. There is no difference between the depression among male and female B.ed college students.

2. There is no difference between the depression among urban and rural B.ed college student.

3. There is no interaction effect of the depression among type of sex and type of area of B.ed college student.

\section{METHODS AND MATERIALS}

\section{Sample:}

Sample in this study consist of 120 subjects the sample were selected in different B.ed colleges in V.V.Nagar. In survey of V.V.Nagar we had got the information about the male and the female staying in urban and rural area. The students which were randomly selected in their 60 were urban area and 60 were rural area. From that 30 male and 30 female used to 
The International Journal of Indian Psychology: Volume: 01 | Issue: 03 | ISSN 2348-5396

study by staying in urban area and the other 30 male and 30 female were used to study by staying rural area.

\section{TOOLS:}

The following tools were used in the present study.

\section{Personal datasheet:}

A personal datasheet developed by the investigator was used to collect information about type of sex and type of area of B.ed college student.

\section{Depression scale}

Depression scale was developed by A.T. Back (1967), was used to measure depression. These are 21 sentences in this scale. All at the sentence had a four option A,B,C, and D. And it can also choosing more than one option. Simple scoring of this scale its A for $0, \mathrm{~B}$ for $1, \mathrm{C}$ for 2 , and $\mathrm{D}$ for 3 respectively. Author has satisfied validity and reliability of this scale.

\section{STATISTICAL ANALYSIS:}

In this study ' $F$ ' test was used for statistical analysis.

\section{RESULT AND DISCUSSION:}

Summary of $2 X 2$ analysis of variance based of Depression of B.ed college student with respect to type of sex and type of area.

Table-1 $(N=120)$

\begin{tabular}{|l|l|l|l|ll|}
\hline Source of variance & $\begin{array}{l}\text { Sum of } \\
\text { square }\end{array}$ & Df & $\begin{array}{l}\text { Mean sum of } \\
\text { square }\end{array}$ & F & \\
\hline (A) Sex & 1353.41 & 1 & 1353.41 & 28.89 & $0.01^{* *}$ \\
\hline (B) Area & 285.21 & 1 & 285.21 & 6.09 & $0.05^{*}$ \\
\hline (AXB)Sex X Area & 357.07 & 1 & 357.07 & 7.62 & $0.01^{* *}$ \\
\hline SSW(Error) & 5433.90 & 116 & 46.84 & & \\
\hline SST & 7429.59 & 119 & & & \\
\hline
\end{tabular}

Mean score of difference of mean of Depression of B.ed college student with respect of type of sex and type of area. 
Table $2 \quad(N=120)$

\begin{tabular}{|l|l|l|l|}
\hline Independent variable & $\mathrm{N}$ & Mean & Difference \\
\cline { 1 - 3 } Male A1 & 60 & 13.07 & \multirow{2}{*}{3.08} \\
\cline { 1 - 3 } Female A2 & 60 & 16.15 & \\
\cline { 1 - 3 } UrbunB1 & 60 & 11.25 & \multirow{2}{*}{6.72} \\
\cline { 1 - 3 } Rural B2 & 60 & 17.97 & \\
\hline
\end{tabular}

According to table No. 1 it is observed that "F" value of Depression of male and female b.ed student is 28.89 which is significant difference even at 0.01 levels. Looking at the table No.2 it can be seen mean score of Depression of male and female are 13.07 and 16.15. The difference between them is 3.08 from there result. It can be said there is significant difference in Depression among male and female of B.ed student and null hypothesis is rejected. And result shows there is high Depression in female than male B.ed college student.

According to table No. 1 it is observed that "F" value of Depression of urban and rural B.ed student is 6.09 which is significant difference even at 0.05 levels. Looking at the table No.2 it can be seen mean score of Depression of urban and rural are 11.25 and 17.97. The difference between them is 6.72 from there result. It can be said there is significant difference in Depression among male and female of B.ed student and null hypothesis is rejected. And result shows there is high Depression in rural areas than urban area's B.ed college student.

According to table No. 1 it is observed that "F" value of Depression of sex and area of b.ed student is 7.62 which is significant difference even at 0.01 levels. The mean value is due to uncertainty situation and its show minimum of size. There is significant interaction effect between sex and area. So Null Hypothesis is rejected.

\section{CONCLUSION:}

1. There is high Depression in female than male B.ed college student.

2. There is high Depression in rural areas than urban area's B.ed college student.

3. There is significant difference between the effect of interaction on Depression among type of sex and type of area of B.ed college student.

\section{Reference:}


The International Journal of Indian Psychology: Volume: 01 | Issue: 03 | ISSN 2348-5396

Back A.T., (1967). Manual of depression scale.

> Copeland, Mary., (1992). The Depression Work book.

$>$ Rowe, Dorothy., (1991). Breaking the bonds: understanding depression.

$>$ Rowe, Dorothy., (1991). Depression: the way out of your prison. 